\title{
Highly selective anion template effect in the synthesis of constrained pseudopeptidic macrocyclic cyclophanes
}

\author{
Ferran Esteve, ${ }^{\text {a }}$ Belen Altava, ${ }^{* *}$ Michael Bolte, ${ }^{b}$ M. Isabel Burguete, ${ }^{a}$ Eduardo García-Verdugo, ${ }^{\text {a San- }}$ \\ tiago V. Luis ${ }^{\mathrm{a} *}$ \\ a Departamento de Química Inorgánica y Orgánica, Universitat Jaume I, Av. Sos Baynat s/n, 12071, Castellón, Spain \\ Corresponding Authors:*e-mail: luiss@uji.es; altava@uji.es.
}

b Institut fur Anorganische Chemie, J. W. Goethe-Universitat Frankfurt, 60438, Frankfurt/Main, Germany

KEYWORDS pseudopeptides, macrocycles, template effects, anions

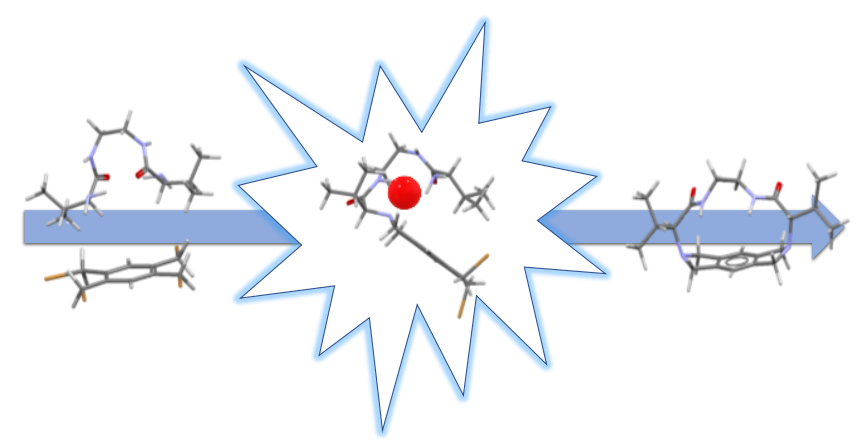

\begin{abstract}
Herein, we report the synthesis of a novel family of constrained pseudopeptidic macrocyclic compounds containing the hexahydropyrrolo[3,4-f] isoindolocyclophane scaffold and involving four coupled substitution reactions in the macrocyclization process. Although the increase in the number of steps involved in the macrocyclization could lead to a larger number of possible side products, the optimization of the methodology and the study of the driving forces, has made possible to obtain the desired macrocycles in excellent yields. A thorough computational study has been carried out to understand the macrocyclization process and the results obtained nicely agree with experimental data. Moreover, bromide anion had a clear catalytic template effect in the macrocyclization reaction, and surprisingly the chloride anion had a negative template effect in opposition to the results obtained for analogous macrocycles. The parameters responsible of the specific kinetic template effect observed have been studied in detail.
\end{abstract}

\section{INTRODUCTION}

Macrocyclic compounds play an important role in nature, having found important applications in host-guest chemistry, catalysis, sensing and for planning and construction of new materials, ${ }^{1}$ and, particularly, cyclopeptides have been shown to take part in important biological functions. ${ }^{2}$

The synthesis of macrocyclic compounds usually requires an important synthetic effort, the macrocyclization step being often yield limiting. ${ }^{3}$ This step needs to efficiently compete with intermolecular dimerization and oligomerization processes and requires an efficient preorganization of the intermediate species. ${ }^{4}$ In this regard, it has been described that an U-turn preorganization in pseudopeptides can favor the intramolecular processes over the intermolecular ones, providing simple routes for the preparation of the related macrocyclic structures. ${ }^{5}$ As a matter of fact, the presence of folded conformations has been associated to the outcome of macrocyclization reactions in many peptides and pseudopeptides. ${ }^{6}$
Several structural units such as urea, proline residues, rigid aromatic units, etc., have been associated with the formation of $\alpha-, \beta-, \gamma$ - or related U-turns.7 Such arrangements, with the appropriate orientation, provide an unencumbered trajectory of attack, accelerating the intramolecular macrocyclization process. Polycations, oligoamides and peptidic structures can develop strong supramolecular interactions with anions, ${ }^{8}$ facilitating their appropriate folding and providing access to efficient macrocyclization processes. ${ }^{9}$ The selection of the suitable anion can be crucial, as anions can act either as kinetic or as thermodynamic templates, stabilizing the corresponding transition state or final macrocycle through specific supramolecular interactions. ${ }^{10}$

In the framework of previous studies on minimalistic pseudopeptidic compounds, ${ }^{11,12}$ the efficient preparation of macrocyclic structures was achieved through the reaction of $C_{2}$ symmetric pseudopeptides with bis(halomethyl)arenes. This was based, in some cases, on the proper conformational and configurational preorganization of the open-chain precursors, ${ }^{13}$ 
while, in other instances, the use of anionic templates allowed high yielding macrocyclization processes, even for systems for which conformational or configurational factors were unfavourable. ${ }^{14}$ The first generations of polyazacyclophanes prepared in this way were highly dynamic, behaving as minimalistic models of molecular rotors, 15 and displayed interesting self-assembly, ${ }^{16}$ molecular recognition and sensing properties.11,17 In this context, the design and preparation of more rigid related systems is of interest considering the role of preorganization in supramolecular properties. ${ }^{18}$

Herein, we report the synthesis of a novel family of conformationally constrained pseudopeptidic macrocycles (3), for which the macrocyclization requires four consecutive substitution reactions competing with the corresponding intermolecular processes and where the role of the halide anions present is key to achieve excellent results.

\section{RESULTS AND DISCUSSION}

Open-chain pseudopeptides 1a-e were prepared starting from the corresponding commercially available protected amino acid as has been previously described. ${ }^{13}$

The macrocyclization between 1a and tetrakis(bromomethyl)benzene 2 (Scheme 1) was assayed under different conditions (ESI, Table S1). Best yields, as determined by ${ }^{1} \mathrm{H}$ NMR, were obtained using $\mathrm{Cs}_{2} \mathrm{CO}_{3}$ as base and $\mathrm{CH}_{3} \mathrm{CN}$ as solvent ( $95 \%$ yield after $3 \mathrm{~h}$ of reaction at $90{ }^{\circ} \mathrm{C}$, entry 11 , table S1). It has to be mentioned that in the absence of $\mathrm{Cs}_{2} \mathrm{CO}_{3}$ the maximum yield obtained was $50 \%$, suggesting that 1a acted as the base neutralizing the ammonium salts formed after each $\mathrm{N}$-alkylation, as has been observed before for related macrocyclization processes (entry 7, Table S1). ${ }^{10 \mathrm{~d}}$ The ESI-MS ( + ) of the crude of the reaction showed an intense peak at $\mathrm{m} / \mathrm{z} 385.2$ associated to $[\mathbf{3 a}+\mathrm{H}]^{+}$and the complete absence of signals corresponding to the open-chain intermediate or the $[2+2]$ or other $[n+n]$ macrocycles. The small peak observed at $\mathrm{m} / \mathrm{z} 769.5$ was assigned to the $[\mathbf{3 a}+\mathbf{3 a}+\mathrm{H}]^{+}$ cluster, as confirmed by MS/MS experiments (ESI, Figure S1ab). ${ }^{19}$ When apolar solvents like $\mathrm{DME}, \mathrm{CHCl}_{3}$ or toluene were assayed, no reaction could be observed, which can be assigned to the lack of solubility of either the reagents or the base needed. On the other hand, when ethanol or DMF were used, a noteworthy decrease in the efficiency of the macrocyclization was detected, most likely associated to the interference with the hydrogen bonding patterns that can be essential for a proper preorganization of the intermediates.

\section{Scheme 1. Syntheses of pseudopeptidic macrocycles.}

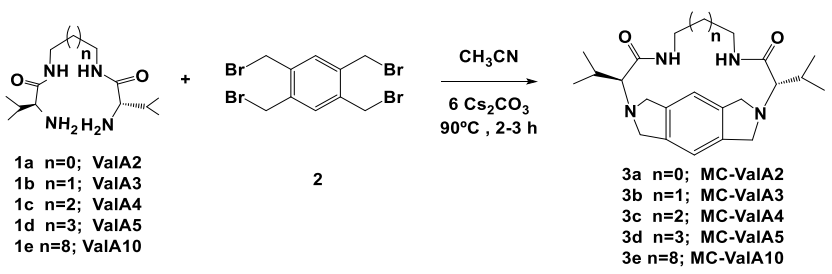

Figure 1 shows the ${ }^{1} \mathrm{H}$ NMR spectra obtained for the reaction between $1 \mathrm{a}$ and 2 at different reaction times $\left(90{ }^{\circ} \mathrm{C}, \mathrm{CD}_{3} \mathrm{CN}\right)$. The disappearance of reagents was followed by monitoring the $\mathrm{H}_{\mathrm{A}}$ aromatic signal for 2 and the $\mathrm{H}_{\mathrm{B}}$ and $\mathrm{H}_{\mathrm{C}}$ valine signals for 1a. The formation of 3a was followed through the appearance of the signals for the aromatic $\left(\mathrm{H}_{D}\right)$, benzylic $\left(\mathrm{H}_{\mathrm{E}}, \mathrm{H}_{\mathrm{F}}\right)$, chiral $\left(\mathrm{H}_{\mathrm{G}}\right)$ and valine $\left(\mathrm{H}_{\mathrm{H}}\right.$ and $\left.\mathrm{H}_{\mathrm{I}}\right)$ protons. It must be noted that, upon cyclization, significant upfield shifts were observed for the signals of the methylene groups $\left(\mathrm{H}_{J}\right)$ of the central spacer, in good agreement with the results observed for other related polyaza[n]cycloalcanes ${ }^{20}$ and cyclic pseudopeptides. ${ }^{13}$ The large anisotropy observed for the two hydrogen atoms of different methylene groups confirms also a high level of conformational constrain. It must be noted that no relevant peaks for other species were detected during this transformation, which highlights the remarkable selectivity of this macrocyclization process where once the first $\mathrm{N}-\mathrm{C}$ bond is formed the intramolecular formation of the other three N-C bonds need to compete efficiently with related intermolecular reactions leading to oligomers or polymers.

As could be expected, a significant effect of the nature of the spacer on the macrocyclization yield was observed at $3 \mathrm{mM}$ concentration (Table 1). For open-chain pseudopeptides with longer aliphatic spacers $(n \geq 1)$ the selectivity decreases as the length of the spacer increases, with the formation of poly- or oligomeric side products, as evidenced by ESI-MS and ${ }^{1} \mathrm{H}$ NMR spectra (ESI, Figures S2 and S3). Still, although longer aliphatic chains can disfavor the intramolecular hydrogen-bonding that leads to a favorable U-fold preorganization, cyclization yields were also good for precursors 1d-e (> 50\% selectivity). The presence of amide functionalities seems to play a key role in such remarkable macrocyclization yields, as confirmed by results obtained using $\alpha, \omega$-diamines instead of diaminodiamides 1. Thus, for instance, the reaction using 1,8diaminooctane yielded a highly insoluble oligomeric/polymeric material with the total absence of the macrocyclic product.

Table 1. Yield obtained for the macrocyclization reaction between 1a-e and 2. ${ }^{a}$

\begin{tabular}{|c|c|c|c|c|}
\hline Entry & $\begin{array}{c}\text { Macrocy- } \\
\text { cle }\end{array}$ & $\begin{array}{c}\text { Conver- } \\
\text { sion (\%) }^{\mathrm{b}}\end{array}$ & $\begin{array}{c}\text { Selectivity } \\
(\%)^{\mathrm{b}}\end{array}$ & $\begin{array}{c}\text { Isolated } \\
\text { Yield (\%) }\end{array}$ \\
\hline 1 & $3 \mathrm{a}$ & $>99$ & 99 & $85^{\mathrm{c}}$ \\
\hline 2 & $3 \mathrm{~b}$ & $>99$ & 90 & $78^{\mathrm{c}}$ \\
\hline 3 & $3 \mathrm{c}$ & $>99$ & 76 & $69^{\mathrm{c}}$ \\
\hline 4 & $3 \mathrm{~d}$ & $>99$ & 59 & $32^{\mathrm{d}}$ \\
\hline 5 & $3 \mathrm{e}$ & $>99$ & 51 & $29^{\mathrm{d}}$ \\
\hline
\end{tabular}

${ }^{\text {a }} \mathrm{CH}_{3} \mathrm{CN}, 3 \mathrm{~h}$ of reaction, $90{ }^{\circ} \mathrm{C}$. ${ }^{\mathrm{b}}$ Determined by ${ }^{1} \mathrm{H}$ NMR. ${ }^{\mathrm{c}}$ Isolated yield after treatment with basic water. ${ }^{d}$ Isolated yield after chromatographic purification. 


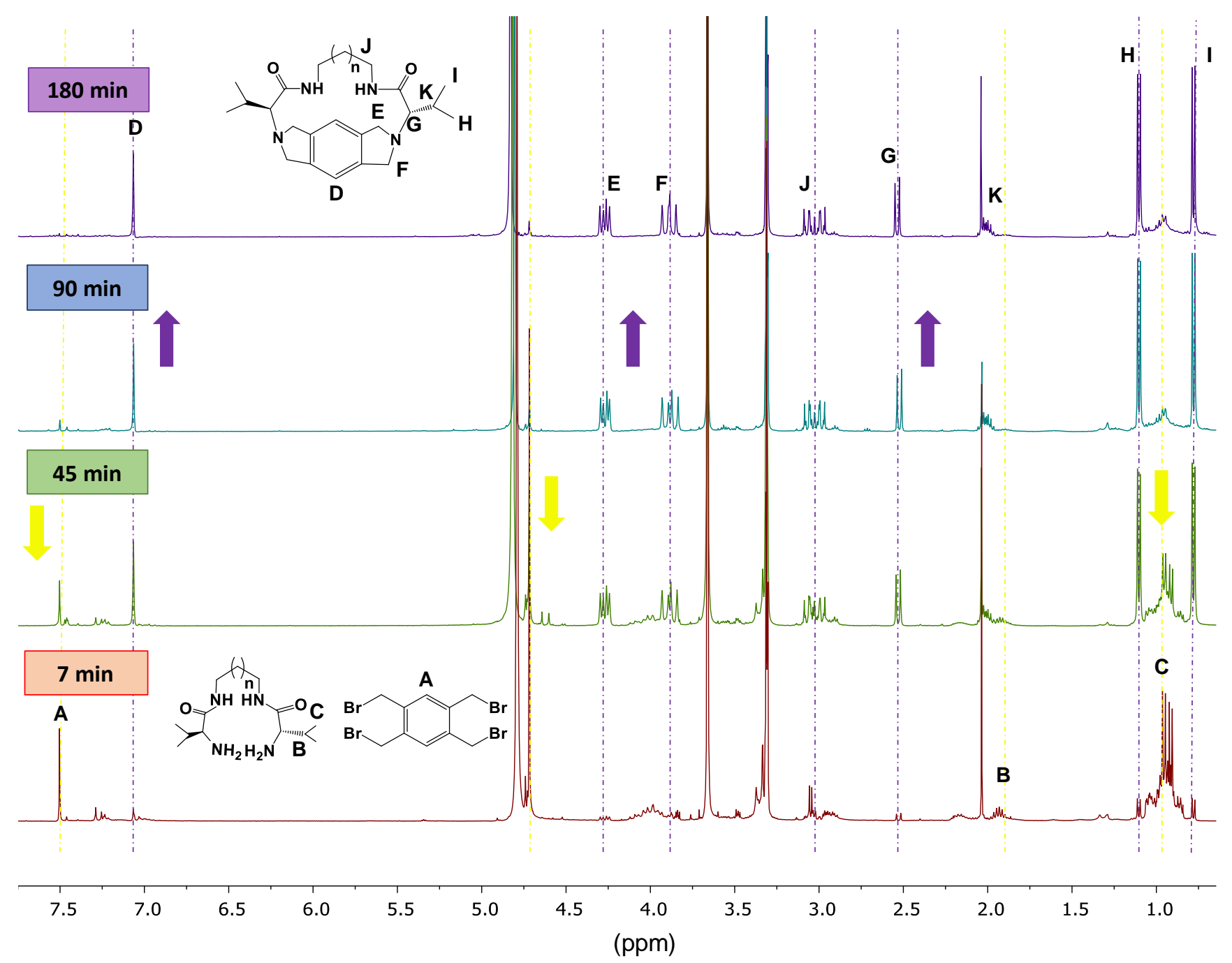

Figure $1 .{ }^{1} \mathrm{H}$ NMR spectra for the reaction between $\mathbf{1 a}$ and $\mathbf{2}$ in $\mathrm{CD}_{3} \mathrm{CN}$ at $90{ }^{\circ} \mathrm{C}$. Upward arrows indicate macrocycle $3 \mathrm{a}$ formation, and downward arrows indicate disappearance of open-chain precursor $\mathbf{1 a}$ and tetrakis(bromomethyl)benzene $\mathbf{2}$.

Computational studies were also carried out to shed light on these processes. For this purpose, the open chain intermediates, generated from 1 a-e after the two initial $S_{N} 2$ reactions had taken place with the formation of the isoindoline structure, were fully optimized using molecular mechanics at the MMFF level of theory with the Spartan08 program (Figure 2). ${ }^{21}$ All intermediates displayed folded conformations driven by intramolecular hydrogen bonds. For compounds with shorter spacers (Figure 2a-b) the minimum energy conformers contained intramolecular hydrogen bonds involving the amide NH groups and the primary and ternary amine groups at both ends of the pseudopeptidic chain. This achieved U-turn conformations with the two amide groups in syn-disposition. On the contrary, for compounds containing larger spacers (4, 5 and 10 methylene units, Figure 2c-e) the hydrogen bond between one amide $\mathrm{NH}$ and the ternary amine group was preserved, but the hydrogen bonding of the second amide $\mathrm{NH}$ involved the participation of one amide $\mathrm{CO}$ as hydrogen bond

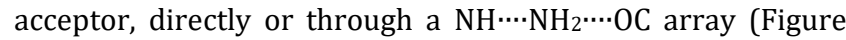
2e). This resulted in the two amide groups displaying an antidisposition. As a result of these conformational preferences, the distance between the nitrogen atom of the primary amino group and the closest carbon atoms of the bromomethyl subunits was significantly shorter for precursors 1a-b than for 1c-e $(6.37,4.74,9.73,10.96$ and $11.61 \AA$ respectively). These shorter $\mathrm{C}-\mathrm{N}$ distances for $\mathbf{1} \mathbf{a}-\mathbf{b}$ should correlate with an increased probability for the intramolecular cyclization reaction in good agreement with experimental results. For the nonpseudopeptidic 1,8-diamineoctane, the minimized structure showed an almost extended conformation in agreement with the low probability of the intramolecular cyclization observed experimentally (ESI, Figure S4).

On the other hand, the smaller involvement of the nitrogen lone pairs of the primary amino groups in the intermediates displaying longer spacers is in good agreement with the higher reactivity observed for the corresponding pseudopeptides. HPLC analysis allowed monitoring the conversion of tetrakis(bromomethyl)benzene (2). For precursors 1c-e the total consumption of $\mathbf{2}$ was achieved after two hours of reaction, whereas almost $3 \mathrm{~h}$ were needed for $\mathbf{1 a - b}$ (Figure 3 ). 
a)

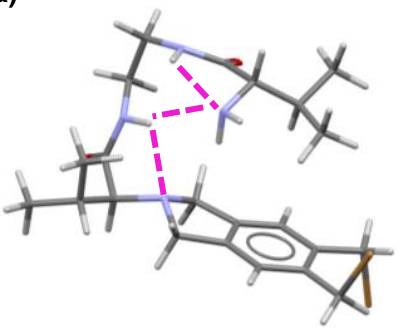

b)

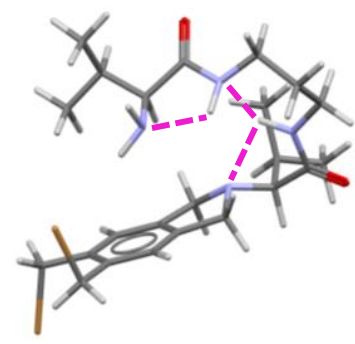

c)

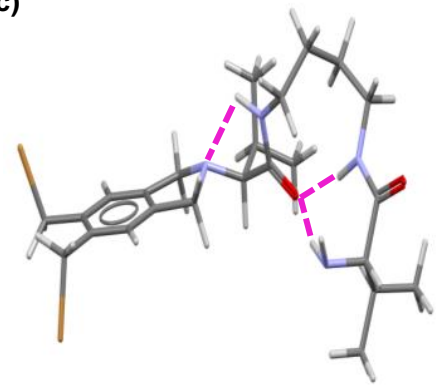

d)

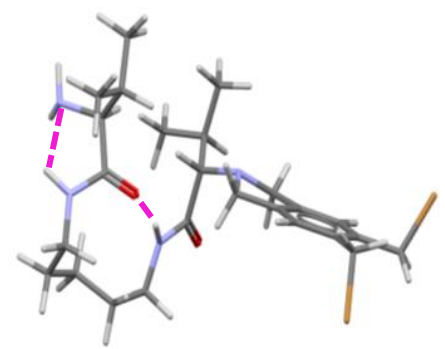

e)

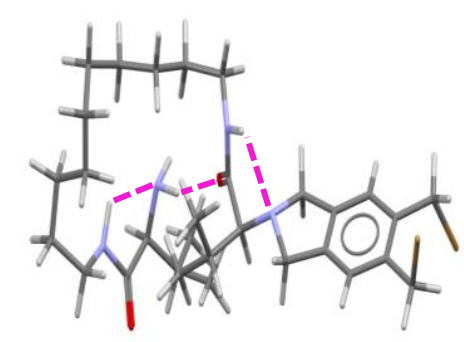

Figure 2. Minimum energy conformers calculated for the corresponding intermediates when precursors 1a-e were used.

Furthermore, ESI-MS analysis of the reaction crude obtained in competitive experiments using an equimolecular mixture 1a-e (1 equiv. each) and 2 (1 equiv.) ( $\mathrm{CH}_{3} \mathrm{CN}, 24$ h, ESI, Figure S5a) revealed that the preference for the formation of the corresponding [1+1] macrocycles followed the order $\mathbf{3 a}>\mathbf{3} \mathbf{b}$ $>$ 3c $>$ 3d $>$ 3e (ESI, Figure S5b). This confirmed the strong selectivity towards the macrocyclization process for the open chain pseudopeptides with the shorter central aliphatic spacers, despite their slightly lower reactivity.

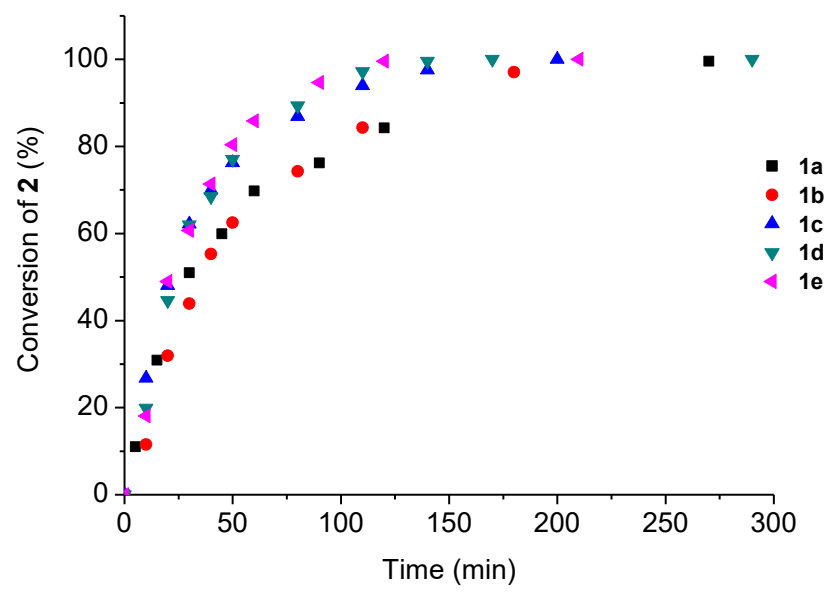

Figure 3. Kinetic profiles of the macrocyclization reaction between 1a-e ( $3 \mathrm{mM})$ and $2(3 \mathrm{mM})$, using acetonitrile as solvent at $90^{\circ} \mathrm{C}$. The conversion was determined by HPLC.

All the macrocyclic products could be purified to isolate the pure compounds in $29-85 \%$ yields and were fully characterized by spectroscopic and ES-MS techniques. Further confirmation of the expected structures was obtained by X-Ray diffraction. Single-crystals suitable for this technique were obtained for compounds $\mathbf{3 a} \mathbf{3} \mathbf{3} \mathbf{b}$ and $\mathbf{3 e}$ by slow evaporation of methanol. Only a partial resolution could be achieved for the crystal obtained from 3d, but the results also confirmed the formation of the macrocyclic structure. Figure 4 shows the molecular structures for $\mathbf{3 a} \mathbf{a} \mathbf{3}$ and $\mathbf{3 e}$ (see also ESI, Figures S13-S15). a)

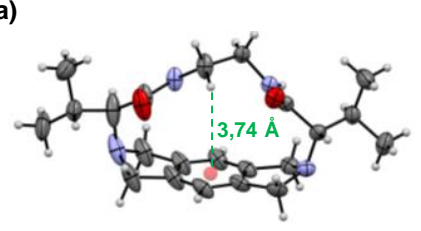

b)

c)
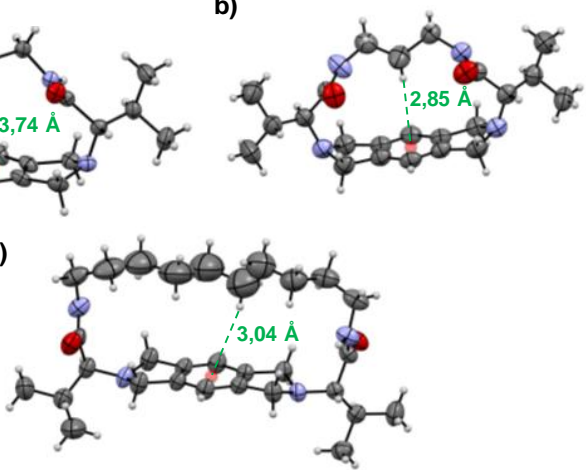

Figure 4. Molecular structures of macrocycles a) $\mathbf{3 a}$, b) $\mathbf{3 b}$ and c) 3e. Distances from the centroid of the aromatic moiety to the closest $\mathrm{H}$ of the aliphatic spacer have been highlighted in green. Ellipsoids at $50 \%$ of probability.

As can be observed in Figure 4, the amide groups are essentially coplanar for the largest macrocyclic compound 3e (amide-amide angle $21^{\circ}$ ), whereas for $\mathbf{3} \mathbf{a}$ and $\mathbf{3 b}$ the amides lay in almost perpendicular planes $\left(67^{\circ}\right.$ and $87^{\circ}$ respectively, ESI, Figure S16). Remarkable differences are observed in the structure of the five-membered rings. For $\mathbf{3 a}$ and $\mathbf{3 b}$ the nitrogen atom is located above the aromatic ring plane, while for 3e both nitrogen atoms are below this plane. An intermediate situation is present in the partly resolved structure of 3d, with each nitrogen atom located at a different side of the aromatic plane (ESI, Figure S17). The presence of intramolecular aromatic-H contacts is highlighted in Figure 4, with centroid-H distances following the order $\mathbf{3} \mathbf{b}<\mathbf{3 e}<\mathbf{3 a}$.

For macrocycles $\mathbf{3} \mathbf{a}$ and $\mathbf{3} \mathbf{b}$ the packing is stabilized by strong parallel amide-amide $\mathrm{H}$-bonds in columnar stacks providing well-defined $\beta$-sheet like arrangements. However, for compound $3 \mathbf{e}$ the amide groups are in an antiparallel disposition with the hydrogen bonding network involving amide-amide 
$\mathrm{H}$-bonds between one molecule and four adjacent ones (ESI, Figure S18). Hydrophobic interactions that are essential for the structural stability of biomolecules in water, ${ }^{22}$ in particular for the organization and assembly of peptides and proteins, ${ }^{23}$ are also key for the final 3D packing as in other pseudopeptidic systems. ${ }^{24}$ Hydrophobic interactions involve preferentially weak isopropyl-isopropyl and isopropyl-aromatic contacts for $\mathbf{3 a}$ and $\mathbf{3 b}$ while $\mathbf{3 e}$ displays aromatic-methylene and isopropyl-methylene contacts involving the long aliphatic spacer (ESI, Figures S19-S21).

As much as four bromide anions are generated for each macrocycle formed, an anion effect can be expected for this process according to previous results in this field. ${ }^{9-13}$ When the macrocyclization using 1a was carried out in the presence of 10 equiv. of $\mathrm{NEt}_{4} \mathrm{Br}$, a clear increase in reaction rate was observed $(100 \%$ conversion and $96 \%$ yield after $1.5 \mathrm{~h}$ against $c a$. $65 \%$ yield in the absence of added salt). A similar kinetic effect was observed for 1d, while for $\mathbf{1 e}$ the effect was very minor (ESI, Figure S6). Nevertheless, no significant differences in the final selectivity were detected after adding 10 equiv. of $\mathrm{NEt}_{4} \mathrm{Br}$ (entries 1, 2 and 3 table 2 vs. entries 1, 4 and 5 table 1). This suggests that one main effect of adding an excess of bromide anions can be the increase of the nucleophilic character of the primary amino groups by efficiently competing with them in the hydrogen bonding to the amide $\mathrm{N}-\mathrm{H}$ fragments, which agrees well with NMR data (ESI, Figure S7).

Table 2. Macrocyclization yields obtained in the presence of an excess of anion. ${ }^{a}$

\begin{tabular}{|c|c|c|c|c|}
\hline Entry & Macrocycle & $\mathrm{X}^{-}$ & $\begin{array}{c}\text { Conver- } \\
\text { sion (\%) }\end{array}$ & $\begin{array}{c}\text { Selectivity } \\
(\%)^{\mathrm{b}}\end{array}$ \\
\hline 1 & $3 \mathrm{a}$ & $\mathrm{Br}^{-}$ & $>99$ & 96 \\
\hline 2 & $3 \mathrm{~d}$ & $\mathrm{Br}^{-}$ & $>99$ & 59 \\
\hline 3 & $3 \mathrm{e}$ & $\mathrm{Br}^{-}$ & $>99$ & 47 \\
\hline 4 & $3 \mathrm{a}$ & $\mathrm{I}^{-}$ & $>99$ & 82 \\
\hline 5 & $3 \mathrm{a}$ & $\mathrm{Cl}^{-}$ & $>99$ & $\mathrm{nd}^{\mathrm{c}}$ \\
\hline
\end{tabular}

${ }^{\text {a }} \mathrm{CH}_{3} \mathrm{CN}, 1.5$ h, $90 \stackrel{\circ}{\circ} \mathrm{C}$. b Determined by ${ }^{1} \mathrm{H}$ NMR. c Not detected.

In spite of the NMR titration data showing that chloride associates more strongly to 1a than bromide (ESI, Figure S7), the addition of an excess of chloride anion also increased the rate for the conversion of $\mathbf{2}$ but, rather surprisingly, produced a remarkable decrease in the efficiency of the macrocyclization for 1a (table 2, entry 5), leading mainly to the formation of polymeric species as was observed by ${ }^{1} \mathrm{H}$ NMR (ESI Figure S8). Interestingly, this noteworthy negative effect of the chloride anion was also confirmed when the macrocyclization between 1a and tetrakis(chloromethyl)benzene was studied, as only oligomeric compounds were again obtained. Alternatively, an excess of iodide anion also produced an increase in the rate but led to a slight decrease of the macrocyclization yield (table 2 , entry 4). This indicates that the basicity of the anion leading to an increase in the nucleophilicity of the primary groups is not the primary responsible of the efficient macrocyclization and that bromide (and to a lower extent iodide) must play a specific role in the preorganization of the intermediate species leading to macrocycle formation.

The role of other anions was also analyzed, in particular considering that different anion topologies could lead to different macrocyclization products. ${ }^{14 \mathrm{~b}}$ In this regard, carboxylate anions like acetate or terephthalate were studied as potential templates but no significant effect was observed. In both cases, ca. $80 \%$ yields of the $[1+1]$ macrocycle were obtained after $3 \mathrm{~h}$, highlighting that the formed bromide anion plays a key role in the process.

As an analogue to the open chain intermediate preceding the macrocyclization, the pseudopeptide $\mathbf{5 a}$ was prepared from $1 \mathrm{a}$ and bis(bromomethyl)benzene (ESI, Scheme S1). The ${ }^{1} \mathrm{H}$ NMR titration in $\mathrm{CD}_{3} \mathrm{CN}$ of $\mathbf{5 a}$ with $\mathrm{Br}^{-}, \mathrm{I}^{-}$and $\mathrm{Cl}^{-}$, as their $\mathrm{NEt}_{4} \mathrm{X}$ salts, led to significant downfield shifts of the signals for the amine $\mathrm{NH}_{2}$, amide $\mathrm{NH}, \mathrm{C}^{*} \mathrm{H}$ and benzylic protons. As expected, the higher $\Delta \delta$ values were observed for the amide protons, in particular for those closer to the aromatic ring (ESI, Figure S9). For this amide signal the maximum observed downfield shifts after addition of 16 equiv. of anion were $\Delta \delta(\mathrm{NH})=1.02$ $\left(\mathrm{Cl}^{-}\right), 0.45\left(\mathrm{Br}^{-}\right)$and $0.10 \mathrm{ppm}\left(\mathrm{I}^{-}\right)$. All $\Delta \delta$ values followed the order anticipated for the basicity of the corresponding anion, being rather small in the case of iodide. Thus, it was clear that although the reactivity of the amino groups can be related with the basicity of the anion the selectivity in the macrocyclization is not associated to a stronger interaction with a given anion. Interestingly, in the sample from the titration with $\mathrm{Cl}^{-}$the ${ }^{1} \mathrm{H}$ NMR spectrum changed dramatically after one week, showing a significant broadening and splitting of most signals (ESI, Figure S10), suggesting the formation of supramolecular aggregates involving $\mathbf{5 a}$ and the chloride anion. In good agreement with this, DOSY experiments revealed a significantly slower diffusion for the aged sample (ESI, Figure S11).

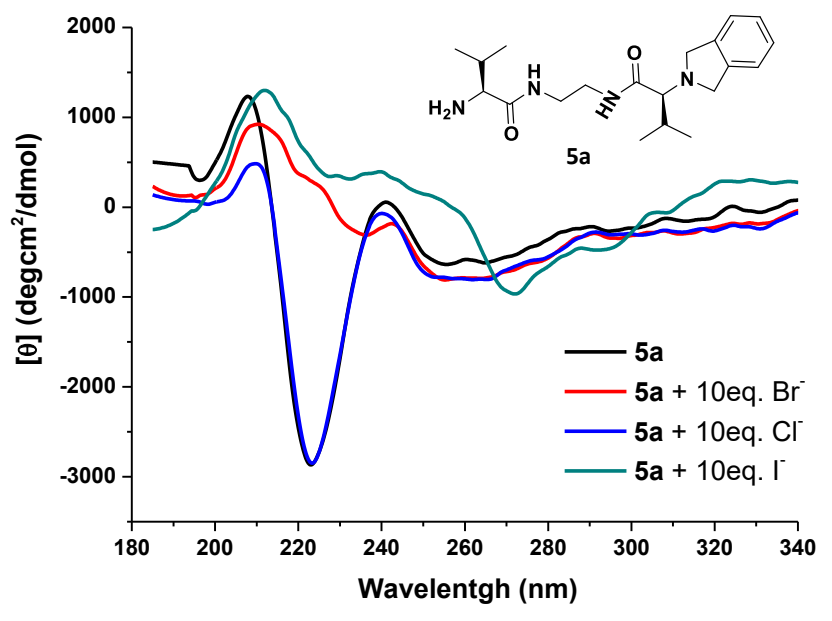

Figure 5. Partial CD spectra of 5a $\left(0.1 \mathrm{mM}\right.$ in $\left.\mathrm{CH}_{3} \mathrm{CN}\right)$ in the absence and presence of 10 equiv. of different anions. a)

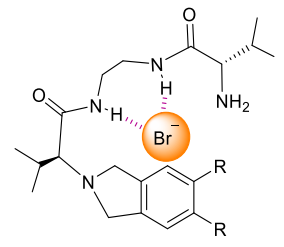

b)

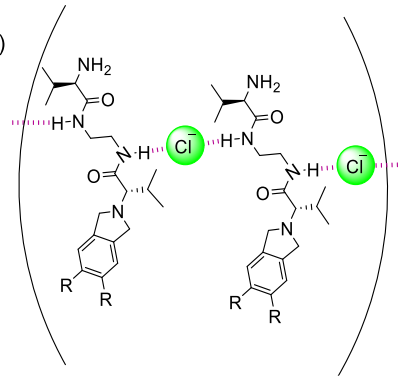

Figure 6. Proposed preorganization of the intermediates during the macrocyclization process in the presence of bromide or chloride template anions. $\mathrm{R}=\mathrm{H}, 5 \mathrm{a}$. $\mathrm{R}=\mathrm{CH} 2 \mathrm{Br}$, macrocyclization intermediate. 
CD also provided interesting data. Figure 5 shows the CD spectra of $\mathbf{5 a}$ obtained in the absence and presence of 10 equiv. of the different anions. The CD spectra of $\mathbf{5 a}$ and $\mathbf{5 a}$ in the presence of chloride were similar, displaying a strong negative CD signal at $223 \mathrm{~nm}$ assigned to $n-\pi$ transitions and a weak negative CD signal at $265 \mathrm{~nm}$ attributed to $\pi-\pi$ transitions. ${ }^{25}$ On the contrary, the CD spectra of $\mathbf{5 a}$ in the presence of bromide and iodide, did not present the negative CD signal at $223 \mathrm{~nm}$, but only the weak negative signal associated to the aromatic moiety at $270 \mathrm{~nm}$.

The results obtained indicate a different preorganization of the intermediate during the macrocyclization process as a function of the interaction with the different anions. According to computational calculations, compound 5a (ESI, Figure S12), presents a minimum energy conformer with the amide groups in antiparallel disposition, facilitating the formation of $\beta$-sheet like aggregates, and justifying the presence of the strong negative CD-band at $223 \mathrm{~nm} .^{25}$ The addition of the most basic and more strongly interacting chloride anion seems to stabilize this antiparallel disposition of amide groups and the formation of aggregates presenting some similarities to $\beta$-sheets. The use of the less coordinating and larger bromide and iodide anions can provide a fully different arrangement with the two amide fragments coordinated to the anion. The parallel disposition of the dipoles for the two amide fragments could explain the disappearance of the corresponding CD signal. If the same considerations are applied to the intermediates in the intramolecular macrocyclization process (Figure 6) it seems clear that the conformation developed through the interaction with bromide (and to a lesser extension iodide) is more appropriately preorganized for the macrocyclization than the one developed in the presence of chloride. Thus, bromide and iodide can act as appropriate macrocyclization templates while chloride acts as an inhibitor (antitemplate) for the same process.

\section{CONCLUSIONS}

The synthesis of a new family of conformationally constrained pseudopeptidic macrocyclic cyclophanes has been carried out in remarkable good yields in $\mathrm{CH}_{3} \mathrm{CN}$ using $\mathrm{Cs}_{2} \mathrm{CO}_{3}$ as base. As evidenced from experimental results and computational calculations, the appearance of properly preorganized intermediates is facilitated by intramolecular $\mathrm{H}$-bonding involving amide and amine functionalities, but also by the presence of the bromide anion that is generated in the process. The presence of anions provides a general kinetic effect increasing the reactivity of the starting diamino bisamide. However, a remarkable differential effect is observed according to the nature of the anion. While bromide, and to a lower extent iodide, seem to act as an efficient template facilitating the [1+1] macrocyclization process, chloride plays an anti-template role, hampering the corresponding cyclization and favoring oligomerization reactions. Our results indicate that the smaller size of the chloride anion and its higher basicity and coordinating capacity is at the origin of this behavior. While chloride can favor strong intermolecular associations of the open-chain intermediate through $\mathrm{NH}_{\text {amide }} \cdots \cdot \mathrm{Cl} \cdots \cdot \mathrm{NH}_{\text {amide }}$ hydrogen bonds, the larger size of the bromide and iodide anions allows establishing intramolecular $\mathrm{NH}_{\text {amide }} \cdots \cdot \mathrm{X}^{-\cdots \cdot} \cdot \mathrm{NH}_{\text {amide }}$ hydrogen bonds that facilitate an appropriate folding of the intermediate for macrocyclization.

\section{EXPERIMENTAL SECTION}

General. NMR experiments were carried out at 400 or 300 $\mathrm{MHz}$ for ${ }^{1} \mathrm{H}$ and 100 or $75 \mathrm{MHz}$ for ${ }^{13} \mathrm{C}$. Chemical shifts are reported in ppm from tetramethylsilane using the solvent resonance as the internal standard. FT-IR spectra were recorded using an ATR adapter. HRMS were recorded with a QTOF instrument. Rotatory power was determined with a digital polarimeter (Na: $589 \mathrm{~nm}$ ). Melting points were measured using a standard apparatus and are uncorrected.

Open chain pseudopeptidic compounds $\mathbf{1}$ were prepared following literature procedures. ${ }^{13}$

General macrocyclization reaction conditions. Synthesis of 3a: 1,8-(S,S)-bis(isopropyl)-2,7-dioxo-3,6-diaza-1,2,3,5,6,7hexahydropyrrolo[3,4-f]isoindolooctaphane. Open chain pseudopeptide 1a (119 $\mathrm{mg}, 0.459 \mathrm{mmol})$ and tetrakis(bromomethyl)benzene 2 (217 $\mathrm{mg}, 0.459 \mathrm{mmol})$ were dissolved in acetonitrile ( $155 \mathrm{~mL})$, together with 6 equivalents of $\mathrm{Cs}_{2} \mathrm{CO}_{3}(897 \mathrm{mg}, 2.754 \mathrm{mmol})$ The reaction mixture was refluxed on a heating mantle with magnetic stirring for 2.5 hours, and then the solvent was evaporated under vacuum. The resulting residue was treated with basic water $(\mathrm{pH} \approx 11)$, centrifuging the final suspension at $3000 \mathrm{rpm}$ for $8 \mathrm{mins}$ and the solid afforded pure 3a. Yield (150 mg, 85.2\%, 0.392 mmol); m.p. $>300^{\circ} \mathrm{C} ;[\alpha]^{25} \mathrm{D}=-32.8^{\circ}(\mathrm{c}=0.5, \mathrm{MeOH})$; IR (ATR): $3263,3053,1623,1531 \mathrm{~cm}^{-1}$; ${ }^{1} \mathrm{H}$ NMR $\left(400 \mathrm{MHz}, \mathrm{CD}_{3} \mathrm{OD}\right) \delta=$ $0.78(\mathrm{~d}, J=6.5 \mathrm{~Hz}, 6 \mathrm{H}), 1.10(\mathrm{~d}, J=6.6 \mathrm{~Hz}, 6 \mathrm{H}), 1.95-2.07(\mathrm{~m}$, $2 \mathrm{H}), 2.51(\mathrm{~d}, J=10.3 \mathrm{~Hz}, 2 \mathrm{H}), 2.94-3.14(\mathrm{~m}, 4 \mathrm{H}), 3.82-3.93$ $(\mathrm{m}, 4 \mathrm{H}), 4.24-4.29(\mathrm{~m}, 4 \mathrm{H}), 7.06(\mathrm{~s}, 2 \mathrm{H}) ;{ }^{13} \mathrm{C}\left\{{ }^{1} \mathrm{H}\right\}-\mathrm{NMR}(100$ $\left.\mathrm{MHz}, \mathrm{CD}_{3} \mathrm{OD}\right) \delta=20.1,20.1,31.5,40.9,55.0,62.6,77.3,117.9$, 141.9, 142.8, 175.3; HRMS (ESI/Q-TOF) m/z: [M + H]+ Calcd for $\mathrm{C}_{22} \mathrm{H}_{33} \mathrm{~N}_{4} \mathrm{O}_{2}$ 385.2604; Found 385.2598.

Synthesis of 3b: 1,9-(S,S)-bis(isopropyl)-2,8-dioxo-3,7diaza-1,2,3,5,6,7-hexahydropyrrolo[3,4-

flisoindolononaphane. This compound was obtained as described above starting from 1b. Yield 78.0\%; m.p. > $300^{\circ} \mathrm{C}$; $\left[\alpha{ }^{25} \mathrm{D}=-65.2^{\circ}(\mathrm{c}=0.5, \mathrm{MeOH}) ; \mathrm{IR}(\mathrm{ATR}) 3337,3071,1621\right.$, $1541 \mathrm{~cm}^{-1}$; ${ }^{1} \mathrm{H}$ NMR (400 MHz, CD $\left.{ }_{3} \mathrm{OD}\right) \delta=0.41(\mathrm{~m}, 2 \mathrm{H}), 0.81$ $(\mathrm{d}, J=6.5 \mathrm{~Hz}, 6 \mathrm{H}), 1.10(\mathrm{~d}, J=6.6 \mathrm{~Hz}, 6 \mathrm{H}), 1.96-2.09(\mathrm{~m}, 2 \mathrm{H})$, 2.38 (ddd, $J=12.8,9.8,7.6 \mathrm{~Hz}, 2 \mathrm{H}$ ), 2.52 (d, $J=10.7 \mathrm{~Hz}, 2 \mathrm{H}$ ), 2.91 (ddd, $J=12.8,9.5,7.4 \mathrm{~Hz}, 2 \mathrm{H}), 3.85(\mathrm{~d}, J=14.9 \mathrm{~Hz}, 2 \mathrm{H})$, $4.14(\mathrm{~d}, \mathrm{~J}=15.4 \mathrm{~Hz}, 4 \mathrm{H}), 4.48(\mathrm{dd}, \mathrm{J}=28.4,15.2 \mathrm{~Hz}, 4 \mathrm{H}), 6.90$ (s, $2 \mathrm{H}) ;{ }^{13} \mathrm{C}\left\{{ }^{1} \mathrm{H}\right\}$-NMR $\left(100 \mathrm{MHz}, \mathrm{CD}_{3} \mathrm{OD}\right) \delta=20.1,20.1,28.5$, 29.8, 37.9, 53.2, 61.5, 77.0, 116.8, 142.2, 173.5; HRMS (ESI/QTOF) m/z: $[\mathrm{M}+\mathrm{H}]^{+}$Calcd for $\mathrm{C}_{23} \mathrm{H}_{35} \mathrm{~N}_{4} \mathrm{O}_{2}$ 399.2760; Found 399.2762

Synthesis of 3c: 1,10-(S,S)-bis(isopropyl)-2,9-dioxo-3,8diaza-1,2,3,5,6,7-hexahydropyrrolo[3,4-

flisoindolodecaphane. This compound was obtained as described above starting from 1c. Yield 69.0\%; m.p. > $300^{\circ} \mathrm{C}$; $[\alpha]^{25} \mathrm{D}=-63.2^{\circ}(\mathrm{c}=0.5, \mathrm{MeOH}) ;$ IR (ATR) 3356, 3070, 1629, $1540 \mathrm{~cm}^{-1} ;{ }^{1} \mathrm{H}$ NMR (400 MHz, CD $\left.{ }_{3} \mathrm{OD}\right) \delta=0.84(\mathrm{~d}, J=6.6 \mathrm{~Hz}$, $6 \mathrm{H}), 0.88-1.04(\mathrm{~m}, 4 \mathrm{H}), 1.10(\mathrm{~d}, J=6.6 \mathrm{~Hz}, 6 \mathrm{H}), 2.03(\mathrm{dq}, J=$ $10.3,6.6 \mathrm{~Hz}, 2 \mathrm{H}), 2.67(\mathrm{~d}, J=10.4 \mathrm{~Hz}, 2 \mathrm{H}), 2.69-2.77(\mathrm{~m}, 2 \mathrm{H})$, $3.13(\mathrm{dt}, J=13.3,7.4 \mathrm{~Hz}, 2 \mathrm{H}), 3.97(\mathrm{~d}, J=14.7 \mathrm{~Hz}, 2 \mathrm{H}), 4.12(\mathrm{~d}$, $J=14.8 \mathrm{~Hz}, 2 \mathrm{H}), 4.44(\mathrm{dd}, J=16.4 \mathrm{~Hz}, 4 \mathrm{H}), 6.94(\mathrm{~s}, 2 \mathrm{H})$; ${ }^{13} \mathrm{C}\left\{{ }^{1} \mathrm{H}\right\}$-NMR $\left(100 \mathrm{MHz}, \mathrm{CD}_{3} \mathrm{OD}\right) \delta=20.2,20.3,26.9,30.5,40.1$, 53.6, 61.5, 76.7, 116.9, 141.0, 141.3, 174.1; HRMS (ESI/Q-TOF) $\mathrm{m} / \mathrm{z}:[\mathrm{M}+\mathrm{H}]^{+}$Calcd for $\mathrm{C}_{24} \mathrm{H}_{37} \mathrm{~N}_{4} \mathrm{O}_{2}$ 413.2917; Found 413.2915 .

Synthesis of 3d: 1,11-(S,S)-bis(isopropyl)-2,10-dioxo-3,9diaza-1,2,3,5,6,7-hexahydropyrrolo[3,4-

flisoindoloundecaphane. This compound was obtained as described above starting from 1d. Yield after purification by 
flash chromatography using $\mathrm{CH}_{2} \mathrm{Cl}_{2}: \mathrm{MeOH}$ (95:5) as the eluent mixture $31.7 \%$; m.p. $>300^{\circ} \mathrm{C}$; $[\alpha]^{25_{\mathrm{D}}}=+20.8^{\circ}(\mathrm{c}=0.2, \mathrm{MeOH})$; IR (ATR) 3288, 3075, 1625, $1547 \mathrm{~cm}^{-1}$; ${ }^{1} \mathrm{H}$ NMR (400 MHz, $\left.\mathrm{CD}_{3} \mathrm{OD}\right) \delta=0.85(\mathrm{~d}, J=6.5 \mathrm{~Hz}, 6 \mathrm{H}), 1.05-0.93(\mathrm{~m}, 4 \mathrm{H}), 1.08(\mathrm{~d}$, $J=6.6 \mathrm{~Hz}, 6 \mathrm{H}), 1.13-1.26(\mathrm{~m}, 2 \mathrm{H}), 2.06(\mathrm{dp}, J=10.7,6.5 \mathrm{~Hz}$, $2 \mathrm{H}), 2.60(\mathrm{dt}, J=13.4,6.6 \mathrm{~Hz}, 2 \mathrm{H}), 2.71(\mathrm{~d}, J=10.7 \mathrm{~Hz}, 2 \mathrm{H})$, $2.79-2.93(\mathrm{~m}, 2 \mathrm{H}), 3.96(\mathrm{~d}, J=14.0 \mathrm{~Hz}, 2 \mathrm{H}), 4.20(\mathrm{~d}, J=13.9$ $\mathrm{Hz}, 2 \mathrm{H}), 4.24-4.39(\mathrm{~m}, 4 \mathrm{H}), 6.97(\mathrm{~s}, 2 \mathrm{H}) ;{ }^{13} \mathrm{C}\left\{{ }^{1} \mathrm{H}\right\}-\mathrm{NMR}(100$ $\left.\mathrm{MHz}, \mathrm{CD}_{3} \mathrm{OD}\right) \delta=20.1,20.2,26.1,29.2,30.4,40.8,53.1,60.5$, 75.3, 117.2, 140.6, 140.8, 173.1; HRMS (ESI/Q-TOF) m/z: [M + $\mathrm{H}]^{+}$Calcd for $\mathrm{C}_{25} \mathrm{H}_{39} \mathrm{~N}_{4} \mathrm{O}_{2}$ 427.3073; Found 427.3070.

Synthesis of 3e: 1,16-(S,S)-bis(isopropyl)-2,15-dioxo-3,14diaza-1,2,3,5,6,7-hexahydropyrrolo $[3,4$ -

f]isoindolohexadecaphane. This compound was obtained as described above starting from 1e. Yield after purification by flash chromatography using $\mathrm{CH}_{2} \mathrm{Cl}_{2}: \mathrm{MeOH}$ (90:10) as the eluent mixture 28.7\%; m.p. $>300^{\circ} \mathrm{C} ;[\alpha]^{25_{\mathrm{D}}}=-9.9^{\circ}(\mathrm{c}=0.1$, $\mathrm{MeOH})$; IR (ATR) 3290, 3077, 1632, $1546 \mathrm{~cm}^{-1} ;{ }^{1} \mathrm{H}$ NMR $(400$ $\left.\mathrm{MHz}, \mathrm{CD}_{3} \mathrm{OD}\right) \delta=0.68-0.8(\mathrm{~m}, 4 \mathrm{H}), 0.86-0.96(\mathrm{~m}, 8 \mathrm{H}), 1.00-$ $1.12(\mathrm{~m}, 12 \mathrm{H}), 1.27-1.41(\mathrm{~m}, 4 \mathrm{H}), 1.42-1.53(\mathrm{~m}, 2 \mathrm{H}), 2.08-$ $2.20(\mathrm{~m}, 2 \mathrm{H}), 2.85(\mathrm{~d}, J=10.1 \mathrm{~Hz}, 2 \mathrm{H}), 2.89-2.96(\mathrm{~m}, 2 \mathrm{H})$, $3.51-3.60(\mathrm{~m}, 2 \mathrm{H}), 4.07-4.20(\mathrm{~m}, 8 \mathrm{H}), 7.01(\mathrm{~s}, 2 \mathrm{H}) ;{ }^{33} \mathrm{C}\left\{{ }^{1} \mathrm{H}\right\}-$ NMR (100 MHz, CD $\left.{ }_{3} \mathrm{OD}\right) \delta=20.0,20.1,28.0,28.8,30.9,31.3$, $31.3,39.3,55.6,62.7,72.8,117.0,139.3,172.1$; HRMS (ESI/QTOF) m/z: $[\mathrm{M}+\mathrm{H}]+$ Calcd for $\mathrm{C}_{30} \mathrm{H}_{49} \mathrm{~N}_{4} \mathrm{O}_{2}$ 497.3856; Found 497.3863.

Synthesis of 5a: (S)-2-amino-N-(2-((S)-2-(isoindolin-2-yl)-3methylbutanamido)ethyl)-3-methylbutanamide. Compound 1a (352 mg, $1.363 \mathrm{mmol}$ ), $\alpha, \alpha^{\prime}$-dibromo-o-xylene 4 (249 mg, $0.908 \mathrm{mmol}$ ) were dissolved in acetonitrile $(250 \mathrm{~mL})$ in the presence of $\mathrm{Cs}_{2} \mathrm{CO}_{3}(1775 \mathrm{mg}, 5.448 \mathrm{mmol})$, and the reaction mixture was refluxed on a heating mantle with magnetic stirring for 5 hours. The solvent was then evaporated under vacuum and the resulting solid was purified by flash chromatography using $\mathrm{CH}_{2} \mathrm{Cl}_{2}: \mathrm{MeOH}(92: 8)$ as the eluent mixture. Yield (99 mg, 30.2\%, $0.275 \mathrm{mmol}$ ); m.p. $=117-119^{\circ} \mathrm{C} ;[\alpha]^{25} \mathrm{D}=-21.6^{\circ}$ (c = 0.2, MeOH); IR (ATR): 3291, 3069, 1639, $1539 \mathrm{~cm}^{-1} ;{ }^{1} \mathrm{H}$ $\operatorname{NMR}\left(400 \mathrm{MHz}, \mathrm{CD}_{3} \mathrm{CN}\right) \delta=0.78(\mathrm{~d}, J=6.8 \mathrm{~Hz}, 3 \mathrm{H}), 0.91(\mathrm{~d}, J=$ $7.0 \mathrm{~Hz}, 3 \mathrm{H}), 0.94(\mathrm{~d}, J=6.7 \mathrm{~Hz}, 3 \mathrm{H}), 1.01(\mathrm{~d}, J=6.8 \mathrm{~Hz}, 3 \mathrm{H})$, $2.00-2.17(\mathrm{~m}, 2 \mathrm{H}), 2.91(\mathrm{~d}, J=6.8 \mathrm{~Hz}, 1 \mathrm{H}), 3.13(\mathrm{~d}, J=4.4 \mathrm{~Hz}$, 1H), $3.22-3.34(\mathrm{~m}, 4 \mathrm{H}), 3.88-4.09(\mathrm{~m}, 4 \mathrm{H}), 7.06(\mathrm{~s}, 1 \mathrm{H}), 7.20$ $(\mathrm{m}, 4 \mathrm{H}), 7.46(\mathrm{~s}, 1 \mathrm{H}) ;{ }^{13} \mathrm{C}\left\{{ }^{1} \mathrm{H}\right\}-\mathrm{NMR}\left(100 \mathrm{MHz}, \mathrm{CD}_{3} \mathrm{OD}\right) \delta=17.7$, 18.8, 19.4, 20.5, 30.1, 32.3, 39.4, 40.4, 56.7, 60.9, 74.1, 123.2, 127.8, 140.6, 173.9, 174.3; HRMS (ESI/Q-TOF) m/z: [M + H] ${ }^{+}$ Calcd for $\mathrm{C}_{20} \mathrm{H}_{33} \mathrm{~N}_{4} \mathrm{O}_{2}$ 361.2604; Found 361.2605.

Crystal structures. Single crystals suitable for X-ray crystallography were obtained by slow evaporation of a solution of the macrocyclic compound in methanol. A suitable crystal was selected and mounted on a SuperNova, Dual, $\mathrm{Cu}$ at zero, Atlas diffractometer. The structure was solved with the SHELXT $2014 / 5^{26}$ structure solution program and refined with the SHELXL-2018/327 refinement package. Artwork representations were processed using MERCURY28 software.

\section{ASSOCIATED CONTENT}

The Supporting Information is available free of charge at http://pubs.acs.org.

Optimization of macrocyclization conditions; ESI-MS and ${ }^{1} \mathrm{H}$ NMR for crude reaction mixtures; ${ }^{1} \mathrm{H},{ }^{13} \mathrm{C}$ NMR and HRMS spectra for all new compounds; kinetic profiles and competitive studies; XRD and computational data; studies for the interaction with anions of different pseudopeptides.

\section{AUTHOR INFORMATION}

Corresponding Author

*E-mail: luiss@uji.es.

*E-mail: altava@uji.es.

Notes

The authors declare no competing financial interests.

\section{ACKNOWLEDGMENT}

This work was supported by the Spanish Ministry of Education, Culture and Sports (RTI2018-098233-B-C22) and Generalitat Valenciana (PROMETEO/2016/071). F. E. thanks Spanish Ministry of Education, Culture and Sports for a predoctoral fellowship (FPU/2017/02060). The support of the SCIC for the different instrumental techniques at Universitat Jaume I is acknowledged.

\section{REFERENCES}

1. (a) Gao, W-X.; Zhang, H-N; Jin, G-H. Supramolecular catalysis based on discrete heterometallic coordination-driven metallacycles and metallacages. Coord. Chem. Rev. 2019, 386, 69-84. (b) Ye, Z.; Yang, Z.; Wang, L.; Chen, L.; Cai, Y.; Deng, P.; Feng, W.; Li, X.; Yuan, L. A Dynamic HydrogenBonded Azo-Macrocycle for Precisely Photo-Controlled Molecular Encapsulation and Release. Angew. Chem. Int. Ed. 2019, 58, 12519-12523. (c) Liu, Z; Nalluri, S. K. M.; Stoddart, J. F. Surveying macrocyclic chemistry: from flexible crown ethers to rigid cyclophanes. Chem. Soc. Rev. 2017, 46, 2459-2478. (d) Joshi, T.; Graham, B.; Spiccia, L. Macrocyclic metal complexes for metalloenzyme mimicry and sensor development. Acc. Chem. Res. 2015, 48, 23662379. (e) Rezaeivala, M.; Keypour, H. Schiff base and nonSchiff base macrocyclic ligands and complexes incorporating the pyridine moiety - The first 50 years. Coord. Chem. Rev. 2014, 280, 203-253. (f) Mewis, R. E.; Archibald, S. J. Biomedical applications of macrocyclic ligand complexes. Coord. Chem. Rev. 2010, 254, 1686-1712.

2. (a) Leroux, M.; Vorherr, T.; Lewis, I.; Schaefer, M.; Koch, G.; Karaghiosoff, K.; Knochel, P. Late-Stage Functionalization of Peptides and Cyclopeptides Using Organozinc Reagents. Angew. Chem. Int. Ed. 2019, 58, 8231-8234. (b) Jafara, M. R.; Yu, H.; Wickware, J. M.; Lin, Y.-S.; Derda, R. Lightresponsive bicyclic peptides. Org. Biomol. Chem. 2018, 16, 7588-7594. (c) D’Amato, A.; Volpe, R.; Vaccaro, M. C.; Terracciano, S.; Bruno, I.; Tosolini, M.; Tedesco, C.; Pierri, G.; Tecilla, P.; Costabile, C.; Della Sala, G.; Izzo, I; De Riccardis, F. Cyclic Peptoids as Mycotoxin Mimics: An Exploration of Their Structural and Biological Properties. J. Org. Chem. 2017, 82, 8848-8863. (d) Thakkar, A.; Trinh, T. B.; Pei, D. Global Analysis of Peptide Cyclization Efficiency. ACS Comb. Sci. 2013, 15, 120-129.

3. (a) Jurczak, J.; Sobczuk, A.; Dąbrowa, K.; Lindner, M.; Niedbała, P. An Indirect Synthetic Approach toward Conformationally Constrained 20-Membered Unclosed Cryptands via Late-Stage Installation of Intraannular Substituents. J. Org. Chem. 2018, 83, 13560-13567. (b) Hammershøj, P.; Beldring, K.; Nielsen, A. R.; Fristrup, P.; Clausen, M. H. Observations on the Influence of Precursor Conformations on Macrocyclization Reactions. Eur. J. Org. Chem. 2016, 8, 1533-1540. (c) Segawa, Y.; Miyamoto, S.; Omachi, H.; Matsuura, S.; Senel, P.; Sasamori, T.; Tokitoh, N.; Itami, K. Concise synthesis and crystal structure of [12] cycloparaphenylene. Angew. Chem. Int. Ed. 2011, 50, 3244-3248. (d) Pattarawarapan, R. S.; Roy, S.; Burgess, K. Preferred Secondary Structures as a Possible Driving Force for Macrocyclization. Tetrahedron 2000, 56, 98099818. (e) Miller, S. C.; Blackwell, H. E.; Grubbs, R. H. Appli- 
cation of Ring-Closing Metathesis to the Synthesis of Rigidified Amino Acids and Peptides. J. Am. Chem. Soc. 1996, 118, 9606-9614. (f) Still, W. C.; Galynker, I. Stereospecific synthesis of the C30-C43 segment of palytoxin by macrocyclically controlled remote asymmetric induction. J. Am. Chem. Soc. 1982, 104, 1774-1776.

4. Luis, S. V.; Martí-Centelles, V.; Burguete, M. I.; Pandey, M. Macrocyclization Reactions: The Importance of Conformational, Configurational and Template-Induced Preorganization. Chem. Rev. 2015, 115, 89736-8834.

5. (a) Yuan, L. H.; Zeng, H. Q.; Yamato, K.; Sanford, A. R.; Feng, W.; Atreya, H.; Sukumaran, D. K.; Szyperski, T.; Gong, B. Helical Aromatic Oligoamides: Reliable, Readily Predictable Folding from the Combination of Rigidified Structural Motifs. J. Am. Chem. Soc. 2004, 126, 16528-16537. (b) Cavelier-Frontin, F.; Pepe, G.; Verducci, J.; Siri, D.; Jacquier, R. Prediction of the best linear precursor in the synthesis of cyclotetrapeptides by molecular mechanic calculations. J. Am. Chem. Soc. 1992, 114, 8885-8890.

6. (a) Horne, W. S.; Gellman, S. H. Foldamers with Heterogeneous Backbones. Acc. Chem. Res. 2008, 41, 1399-1408. (b) Hecht, S.; Huc, I. Foldamers: Structure, Properties, and Applications; Wiley-VCH: Weinheim, 2007. (c) Nakanishi, H.; Kahn, M. in Bioorganic Chemistry: Peptides and Proteines; Hecht, S. M., Ed; Oxford University Press: New York, 1998, Chapter 12. (d) Liu, Z.-P.; Rizo, J.; Gierasch, L. M. Protein folding. In Bioorganic Chemistry: Peptides and Proteines; Hecht, S. M., Ed; Oxford University Press: New York, 1998, Chapter 6. (e) Gellman, S. H. Foldamers: A Manifesto. Acc. Chem. Res. 1998, 31, 173-180.

7. (a) Wellhöfer, I.; Frydenvang, K.; Kotesova, S.; Christiansen, A. M.; Laursen, J. S.; Olsen, C.A. Functionalized Helical $\beta$-Peptoids. J. Org. Chem. 2019, 847, 3762-3779. (b) Plesner, T. M.; Dissing, M. M.; Andersen J-M.; Frydenvang, K.; Nielsen, J. Advances towards Aromatic Oligoamide Foldamers: Synthesis and X-ray Structures of Dimeric Arylopeptoids with Conformation-Directing Side Chains Hjelmgaard. Eur. J. Org. Chem. 2014, 3971-3975. (c) Martinek, T. A.; Fülöp, F. Peptidic Foldamers: Ramping Up Diversity. Chem. Soc. Rev. 2012, 41, 687-702. (d) Horne, W. S. Peptide and Peptoid Foldamers in Medicinal Chemistry. Expert Opin. Drug Discovery 2011, 6, 1247-1262. (e), Nowick, J. S.; Insaf, S. The Propensities of Amino Acids to Form Parallel $\beta$-Sheets. J. Am. Chem. Soc. 1997, 119, 10903-10908.

8. (a) Tyszka, A.; Pikus, G.; Dạbrowa, K.; Jurczak, J. Late-Stage Functionalization of (R)-BINOL-Based Diazacoronands and Their Chiral Recognition of $\alpha$-Phenylethylamine Hydrochlorides. J. Org. Chem. 2019, 84, 6502-6507. (b) Eytel, L. M.; Fargher, H. A.; Haley, M. M.; Johnson, D. W. The road to aryl $\mathrm{CH}---$ anion binding was paved with good intentions: fundamental studies, host design, and historical perspectives in $\mathrm{CH}$ hydrogen bonding. Chem. Commun. 2019, 55, 5195-5206. (c) Mungalpara, D.; Stegmüller, S.; Kubik, S. A neutral halogen bonding macrocyclic anion receptor based on a pseudocyclopeptide with three 5-iodo1,2,3-triazole subunits. Chem. Commun. 2017, 53, 50955098. (d) Dąbrowa, K.; Ulatowski, F.; Lichosyt, D.; Jurczak, J. Catching the chloride: searching for non-Hofmeister selectivity behavior in systematically varied polyamide macrocyclic receptors. Org. Biomol. Chem. 2017, 15, 5927 5943. (e) Tamaki, K.; Ishigami, A.; Tanaka, Y.; Yamanaka, M.; Kobayashi, K. Self-Assembled Boronic Ester Cavitand Capsules with Various Bis(catechol) Linkers: CavityExpanded and Chiral Capsules. Chem. Eur. J. 2015, 21, 13714-13722.

9. (a) Łęczycka-Wilk, K.; Dąbrowa, K.; Cmoch, P.; Jarosz, S. Chloride-Templated Macrocyclization and Anion-Binding Properties of C-2-Symmetric Macrocyclic Ureas from Su- crose. Org. Lett. 2017, 19, 4596-4599. (b) Martí-Centelles, V.; Burguete, M. I.; Luis, S. V. Macrocycle Synthesis by Chloride-Templated Amide Bond Formation. J. Org. Chem. 2016, 81, 2143-2147. (c) Katayev, E. A.; Kolesnikov, G. V.; Arnold, R.; Lavrov, H. V.; Khrustalev, V. N. Templating Irreversible Covalent Macrocyclization by Using Anions. Chem. Eur. J. 2013, 19, 3710-3714. (d) Katayev, E. A.; Pantos, G. D.; Reshetova, M. D.; Khrustalev, V. N.; Lynch, V. M.; Ustynyuk, Y. A.; Sessler, J. L. Anion-Induced Synthesis and Combinatorial Selection of Polypyrrolic Macrocycles. Angew. Chem. Int. Ed. 2005, 44, 7386-7390. (e) Garbleu, N. V; Arion, V. B.; Burgess, J. Template Synthesis of Macrocyclic Compounds, Weinheim, 1999.

10. (a) Kaabel, S.; R. Stein, R. S.; Fomitsenko, M.; Jrving, I.; Friscic, T.; Aav, R. Size-Control by Anion Templating in Mechanochemical Synthesis of Hemicucurbiturils in the Solid State. Angew. Chem. Int. Ed. 2019, 58, 6230-6234. (b) Batiste, S. M.; Johnston, J. N. Evidence for Ion-Templation During Macrocyclooligomerization of Depsipeptides. J. Am. Chem. Soc. 2018, 140, 4560-4568. (c) Satake, A.; Ishizawa, Y.; Katagiri, H.; Kondo, S. Chloride Selective Macrocyclic Bisurea Derivatives with 2,2'-Binaphthalene Moieties as Spacers. J. Org. Chem. 2016, 81, 9848-9857. (d) MartíCentelles, V.; Burguete, M. I.; Luis, S. V. Template Effects in SN2 Displacements for the Preparation of Pseudopeptidic Macrocycles. Chem. Eur. J. 2012, 18, 2409-2422. (e) Lankshear, M. D.; Beer, P. D. Strategic Anion Templation. Coord. Chem. Rev. 2006, 250, 3142-3160. (f) Gimeno, N.; Vilar, R. Anions as templates in coordination and supramolecular chemistry. Coord. Chem. Rev. 2006, 250, 3161-3189. (g) Vilar, R. Anion-Templated Synthesis. Angew. Chem. Int. Ed. 2003, 42, 1460-1477.

11. Luis, S. V.; Alfonso, I. Bioinspired Chemistry Based on Minimalistic Pseudopeptides. Acc. Chem. Res. 2014, 47, 112124.

12. Valls, A.; Altava, B.; Burguete, M. I.; Escorihuela, J.; MartíCentelles, V.; Luis, S. V. Supramolecularly assisted synthesis of chiral tripodal imidazolium compounds. Org. Chem. Front. 2019, 6, 1214-1225.

13. Bru, M.; Alfonso, I.; Burguete, M. I.; Luis, S. V. Efficient syntheses of new chiral peptidomimetic macrocycles through a configurationally driven preorganization. Tetrahedron Lett. 2005, 46, 7781-7785.

14. (a) Moure, A.; Luis, S. V.; Alonso, I. Efficient synthesis of pseudopeptidic molecular cages. Chem. Eur. J. 2012, 18, 5496-5500. (b) Alfonso, I.; Bolte, M.; Bru, M.; Burguete, M. I.; Luis, S. V.; Rubio, J. Supramolecular Control for the Modular Synthesis of Pseudopeptidic Macrocycles through an Anion Templated Reaction. J. Am. Chem. Soc. 2008, 130, 6137-6144.

15. Alfonso, I.; Burguete, M. I.; Galindo, F.; Luis, S. V.; Vigara, L. Molecular Rotors as Simple Models to Study Amide NHAromatic Interactions and Their Role in the Folding of Peptide-like Structures. J. Org. Chem. 2007, 72, 7947-7956.

16. Wadhavane, P. D.; Galian, R. E.; Izquierdo, M. A.; Sigalat, J.; Galindo, F.; Schmidt, L.; Burguete, M. I.; Pérez-Prieto, J.; Luis, S. V. Photoluminescence enhancement of CdSe quantum dots: A case of organogel-nanoparticle symbiosis. J. Am. Chem. Soc. 2012, 134, 20554-20563.

17. Martí-Centelles, V.; Galindo, F.; Izquierdo, M. A.; Kumar, D. K.; White, A. J. P.; Luis, S. V.; Vilar, R. Fluorescent acridinebased receptors for H2P04. J. Org. Chem. 2012, 77, 490500.

18. (a) Gaeta, M.; Raciti, D.; Randazzo, R.; Gangemi, C. M. A.; Raudino, A.; D’Urso, A.; Fragalà, M. E.; Purrello, R. Chirality Enhancement of Porphyrin Supramolecular Assemnbly Driven by a Template Preorganization Effect. Angew. Chem. Int. Ed. 2018, 57, 10656-10660. (b) Wang, Z.; Liang, C.; Shang, Y.; He, S.; Wang, L.; Yang, Z. Narrowing the di- 
versification of supramolecular assemblies by preorganization. Chem. Commun. 2018, 54, 2751-2754. (c) Cram, D. J. Preorganization-From Solvents to Spherands. Angew. Chem. Int. Ed. 1986, 25, 1039-1057.

19. (a) Pan, H. A non-covalent dimer formed in electrospray ionisation mass spectrometry behaving as a precursor for fragmentations. Rapid Commun. Mass Spectrom. 2008, 22, 3555-3560. (b) Konig, S.; Fales, H. M. Formation and Decomposition of Water Clusters as Observed in a Triple Quadrupole Mass Spectrometer. J. Am. Soc. Mass Spectrom. 1998, 9, 814-822.

20. Andres, A.; Burguete, M. I.; Garcia-España, E.; Luis, S. V.; Miravet, J. F.; Soriano, C. Polyazacyclophanes. 2,6,9,13Tetraaza[14] paracyclophane as a cationic and anionic receptor. J. Chem. Soc. Perkin Trans. 1993, 4, 749-755.

21. Deppmeier, B. J.; Driessen, A. J.; Hehre, T. S.; Hehre, W. J.; Johnson, J. A.; Klunzinger, P. E.; Leonard, J. M.; Pham, I. N.; Pietro, W. J.; Jianguo, Y. Spartan '08, build 132 (Mar 27 2009), Wavefunction Inc.: Irvine CA, 2009.

22. (a) Jiang, L.; Cao, S.; Cheung, P. P.-H.; Zheng, X.; Leung, C. W. T.; Peng, Q.; Shuai, Z.; Tang, B. Z.; Yao, S.; Huang, X. Realtime monitoring of hydrophobic aggregation reveals a critical role of cooperativity in hydrophobic effect. Nat. Commun., 2017, 8, 15639-15647. (b) Kinoshita, M.; Hayashi, T. Unified elucidation of the entropy-driven and opposed hydrophobic effects. Phys. Chem. Chem. Phys. 2017, 19, 25891-25904. (c) Ball, P. Water is an active matrix of life for cell and molecular biology. Proc. Natl. Acad. Sci. U. S. A., 2017, 114, 13327-13335. (d) Pratt, L. R.; Pohorille, A. Hydrophobic Effects and Modeling of Biophysical Aqueous Solution Interfaces. Chem. Rev., 2002, 102, 26712692.

23. (a) Hirota, S.; Lin, Y.-W. Design of artificial metalloproteins/metalloenzymes by tuning noncovalent interactions. J. Biol. Inorg. Chem., 2018, 23, 7-25. (b) Tomasini, C.; Zanna, N. Oxazolidinone-containing pseudopeptides: Supramolecular materials, fibers, crystals, and gels. J. Pept. Sci. 2017, 108, e22898. (c) Macedi, E.; Meli, A.; De Riccardis,
F.; Rossi, P.; Smith, V. J.; Barbour, L. J.; Izzo I.; Tedesco, C. Molecular recognition and solvatomorphism of a cyclic peptoid: formation of a stable 1D porous framework. CrystEngComm 2017, 19, 4704-4708. (d) Jang, Y.; Champion, J. A. Self-Assembled Materials Made from Functional Recombinant Proteins. Acc. Chem. Res. 2016, 49, 21882198. (e) Levy Y.; Onuchic, J. N. Mechanisms of Protein Assembly: Lessons from Minimalist Models. Acc. Chem. Res. 2006, 39, 135-142.

24. Gorla, L.; Martí-Centelles, V.; Altava, B.; Burguete, M. I.; Luis, S. V. The role of the side chain in the conformational and self- assembly patterns of C2-symmetric Val and Phe pseudopeptidic derivatives. CrystEngComm 2019, 21, 2398-2408.

25. (a) Ranjbar, B.; Gill, P. Circular Dichroism Techniques: Biomolecular and Nanostructural Analyses- A Review. Chem. Biol. Drug Des. 2009, 74, 101-120. (b) Bulheller, B. M.; Miles, A. J.; Wallace, B. A.; Hirst, J. D. Charge-transfer transitions in the vacuum-ultraviolet of protein circular dichroism spectra. J. Phys. Chem. B. 2008, 112, 1866-1874 (c) Kelly, S. M.; Jess, T. J.; Price, N. C. How to study proteins by circular dichroism. Biochim. Biophys. Acta 2005, 1751, 119-139. (d) Lowe, S. L.; Pandey, R. R.; Czlapinski, J.; KieAdams, G; Hoffmann, M. R.; Thomasson, K. A.; Pierce, K. S. Dipole interaction model predicted pi-pi* circular dichroism of cyclo(L-Pro)3 using structures created by semiempirical, ab initio, and molecular mechanics methods. $J$. Pept. Res. 2003, 61, 189-201.

26. Sheldrick, G. M. A short history of SHELX. Acta Crystallogr. A 2008, 64, 112-122.

27. Sheldrick, G. M. Crystal structure refinement with SHELXL. Acta Crystallogr. C 2015, 71, 3-8.

28. Macrae, C. F.; Bruno, I. J.; Chisholm, J. A.; Edgington, P. R.; McCabe, P.; Pidcock, E.; Rodriguez Monge, L.; Taylor, R.; van de Streek, J.; Wood, P. A. New Features for the Visualization and Investigation of Crystal Structures. J. Appl. Crystallogr. 2008, 41, 466-470. 